\title{
AN ANALYSIS OF POST-CYBERPUNK AS A CONTEMPORARY POSTMODERNIST LITERATURE
}

\author{
Saba Zaidi* \\ Mian Khurram Shahzad Azam**
}

\begin{abstract}
This study is based on Post-cyberpunk in order to highlight the prominence of Postcyberpunk as an emerging representative genre of Postmodern Literature. Technological progress has altered the ontology of being a human in an era of information technology, thus this study aims to critically discuss the issues of identity and representation. Although ample critical work has been done on genre Postcyberpunk yet this study is unique in a way that it is a collection of different discursive practices related to identity crises presented in selected Post-cyberpunk narratives. It targets to critically analyze the alternations and transformations in representation of identity in the backdrop of Postmodernist Deconstruction of Metanarratives by Lyotard (1984). Apart from the deconstruction of metanarratives this study signifies the relevance of Post-cyberpunk as Postmodernist Literature that represents society through multidimensional discursivity such as capitalism, hypercasaulization, imperialism, religion, economy and technology. This study aims to deconstruct the metanarratives of identity that were considered to be permanent and claimed to be power narratives. It equally represents the deconstruction of center/margin dichotomy by bringing mininarratives into the center. The method adopted for research is SocioCognitve Approach by van Dijk (2008) from Critical Discourse Analysis.
\end{abstract}

Keywords: Identity; deconstruction; metanarratives; postmodernism; technology

\section{Introduction}

This research explores and analyzes the Postmodernist tendencies and qualities in selected Post-cyberpunk novels: The wind Up Girl (2009) by Paolo Bacigalupi and Accelerando (2005) by Charles Stross through a Postmodernist deconstruction of Metanarratives. Aim of this study is to express the vision of Science Fiction Literature (Post-cyberpunk) that has always been suppressed under the image of crude Science Fiction themes related to man/alien controversy, and alien space ships invading our world. Post-cyberpunk is critical as it challenges and shows disillusionment with established social structures. Within the Postmodern paradigm there are no constant grand narratives. Identity being also one of the metanarratives has become a liquid phenomenon that is in constant subversion while representations of identity are in rapid

This work is Licensed under a Creative Commons Attribution-Non-Commercial 4.0 International License (c) (i) () ()

\footnotetext{
* Saba Zaidi, Ph.D. Assistant Professor English Department SBK Women's University, Quetta.

** Mian Khurram Shahzad Azam, Ph.D. Additional Director QEC Fatima Jinnah Women University, Rawalpindi
} 
transformations. Digital culture has made identity terminal and identities appear as flickering on computer screens incarnated in multiple representations.

Bukatman $^{1}$, a cultural theorist has rightly termed identity as a terminal phenomenon. In Post-cyberpunk novels technology is invisible not in the sense that it has vanished but invisibility of technology suggests that it has become one with society, which has blurred the binaries between technology and culture. According to Bukatman, it has become complicated to separate human from technology, which has produced a cultural crisis of identity through electronically defined reality. Therefore, Postmodernist discourse has given vent to vital ontological questions with regard to the status of human.

Contemporary era is indeed a period of blurred ontologies where "technology and human are no longer so dichotomous". ${ }^{2}$ Bukatman has further suggested that Science Fiction genre (Cyberpunk) is a true representative of Postmodernist cultural crisis that does not recognizes any solid objective paradigm. To the contrary, it narrates and reveals opaqueness produced by technology in contemporary culture. Jameson ${ }^{3}$ has also acknowledged that Cyberpunk is an ultimate literary representative of Postmodernism and late capitalism. Bukatman has stressed the relevance of Cyberpunk Literature according to him, "Science Fiction offered (and continues to offer) an alternative mode of representation, one more adequate to its era".

Technology in the form of computers has become an agent of Postmodernist ideas for it produces instability of meaning and lack of universal and objective truths. If computers were merely calculation machines in Modern age then in Postmodern age they have become more powerful because they are transformed from calculating apparatus to simulation machines. "The lessons of computing today have little to do with calculation and rules; instead they concern simulation, navigation, and interaction" (Turkle 2011) . Post-cyberpunk/Cyberpunk discourse is an amalgamation of fantasy, mythology, supernatural and reality, its structure gets more complicated with scientific technology. Post-cyberpunk/Cyberpunk Literature speaks of an interdisciplinary approach and depicts that contemporary disciplines are inter-reliant and codependent. "They supplement one another in much the same way as bodies and prostheses do. In the process, new discourses are engendered" (Cavallaro 2000) $)^{5}$. It develops different kinds of relations where technology shapes culture and science forms the epistemological grounds while myth and reality run parallel. Postmodernist theorist like Baudrillard celebrates opacity when he talks about the seductions of technology.

This research is an endeavor to justify that Post-cyberpunk is contemporary, socially relevant and valid. The themes that are discussed and analyzed in Critical Discussion

${ }^{1}$ Scott Bukatman, Terminal Identity: The Virtual Subject in Postmodern Science Fiction. (Durham: Duke UP, 1993)

${ }^{2}$ Ibid., pp.5-7

${ }^{3}$ Fredrick Jameson, Postmodernism, or, the Cultural Logic of Late Capitalism. (Durham: Duke University Press, 1991)

${ }^{4}$ Sherry Turkle, Life on the Screen: Identity in the Age of the Internet. (London: Simon \& Schuster, 2011) 19

${ }^{5}$ Dani Cavallaro, Cyberpunk and Cyberculture: Science Fiction and the Work of William Gibson. (London:

The Athlone Press, 2000), 65 
represent social relevance of Post-cyberpunk Literature and its utilization in contemporary life. In today's technologically progressing society Post-cyberpunk is a vigorous source that produces narratives whether novels or movies, which depict our relation with technology. This relationship is essential to comprehend for contemporary society has become technically and socially dynamic. It is exclusive to Post-cyberpunk subgenre that it aptly articulates the aspects and apprehensions of Postmodernist contemporary life. Furthermore, it provides a consideration for emergent innovative subjectivities and pluralities. These narratives contextualize different sectors of culture whether economic, religious, political, social and technological.

\section{Literature Review}

Since the advent of humanity, technological advancement has altered culture in drastic ways. Thus, it would not be wrong to suggest that it is essentially the technology, which has produced revolutionary transformations in society to such an extent that technology has become a significant element in evolution process of humanity. The computers of information technological era have provided individuals with new perceptions that have and will alter their lives in significant ways. One of these possibilities is collapse of totalitarian regimes that has controlled the twentieth century after World War II. Technology has now become a generalized process that affects every level of society. In the industrial societies factory-based production was means of control, a hierarchy based bureaucratic market economy. While in information age production is not the means of control rather control by means of communication is a key to power (Richardson 2001) . $^{6}$

Postmodern techno-culture is a human artifact shaped over and against nature that is subject to human manipulations. Culture is also based on similar information patterns that grow from human actions. Cultural theorists have initiated to conceptualize everyday life in late twentieth and early twenty-first century. Their argument is based on the concept that everyday life can no longer be defined as a homogenous phenomenon but it is and it should be comprehended as a pluralistic and contested field. The transformation of everyday life is based on many interrelated factors most significant of them is the rupture of modernity that has consequently reduced the importance of modernist conceptions of identity represented in the form of class, race, gender and occupation. Second factor is pervasiveness of media and cultural industries that has shifted the role of social identity (Bennett 2005) ${ }^{7}$. In the backdrop of late modernity both culture and everyday life are complex and hybrid concepts. Crisis of our everyday culture is a crisis of identity. Post-cyberpunk genre is an apt representative of everyday culture. It portrays complex scenarios of media culture with its fluid and liquid identities, "Science Fiction offered (and continues to offer) an alternative mode of representation, one more adequate to its era ..." (Bukatman 1993) ${ }^{8}$.

Many writers have used the term Postmodernism in 1950s and 1960s but the concept of Postmodernism thoroughly developed in mid of 1970s. Since then Postmodernist phenomenon continues to exist in diverse social and cultural disciplines such as

\footnotetext{
${ }^{6}$ Michael Richardson, The Experience of Culture. (London: Sage Publication, 2001)

${ }^{7}$ Andy Bennett, Culture and Everyday Life. (London: Sage Publications, 2005)

${ }^{8}$ Scott Bukatman, Op.cit.
} 
education, philosophy, art and architecture, film and literary studies. Cornor ${ }^{9}$ has argued that "With the appearance of Jean-François Lyotard's La Condition Postmoderne in 1979, and its translation into English in 1984, these different disciplinary diagnoses received an interdisciplinary confirmation, and there no longer seemed room for disagreement that postmodernism and postmodernity had come to stay". Definitely, with such a success Postmodernism has sustained a lot of controversies, whatsoever Postmodernism adequately represents the contemporary culture. "Postmodern theory is an attempt to understand a media-saturated society. For example, the mass media were once thought to hold a mirror up to a wider social reality, and thereby reflect it. Now reality can only be defined by the surface reflections of this mirror" (Strinati 1995) ${ }^{10}$.

Postmodern culture and society are subsumed within mass media to such an extent that there remains no sense of distorted reality for now there is a reality external to surface simulations created by media that is being altered. Therefore, simulated reality is the only reality with which we are left. Postmodern has now become an interdisciplinary arena of economy, art, culture (popular and mass), politics and literary discourses. Postmodern is the culture that is outside history without linear concepts of time and space. The Postmodernist stance is skeptical of all kinds of metanarratives and it surges that they are disintegrated, and have lost their legitimacy and validity in information oriented current society (Strinati 1995). Postmodern shift is evident in every aspect of contemporary society from architecture, art, literature, cinema, television, advertising, pop music to education, politics and economy. Postmodern theory suggests that fix meanings have been subsumed by a series of representations that have floating signifiers, which has turned the real into hyperreal. Postmodern is not a movement rather it is a condition, a predicament that is suggestive of competing definition and intentions. "--- postmodernism relates to significant social transformations that have been taking place at the global level since at least the end of the Second World War. At the root of these transformations, it is argued, is a declining belief in the defining ideas and principles of the Enlightenment project" (Bennett 2005) ${ }^{11}$.

According to $\mathrm{McHale}^{12}$ the dominant of Modernist fiction is epistemological in nature that is Modernist fiction deals and foreground philosophical questions based upon nature of world and knowledge. While the dominant of Postmodernist fiction is ontological that is it deals and foreground 'post-cognitive' questions related to world. So "postmodernist fiction does hold the mirror up to reality; but that reality, now more than ever before, is plural" (McHale 1987). Hassan has also stressed upon pluralism as he has suggested that "the age demands differences, shifting signifiers, and even atoms dissolve into elusive sub-particles..."13.

\footnotetext{
${ }^{9}$ Steven Connor, Postmodernist Culture : An Introduction to Theories of the Contemporary, ${ }^{\text {nd }}$ ed. (Malden Massachusetts: Blackwell Publishing Ltd, 1997), 6

${ }^{10}$ Dominic Strinati, An Introduction to Theories of Popular Culture. (New York: Routledge, 1995) 211-212

${ }^{11}$ Andy Bennett, Culture and Everyday Life. (London: Sage Publications, 2005) 33

${ }^{12}$ Brian McHale, Postmodernist Fiction. (GB: Methuen, Inc., 1987) 37-39

${ }^{13}$ Ihab Hassan. Pluralism in Postmodern Perspective. Critical Inquiry, no 12.3, (1986): 503
} 
According to Lyotard ${ }^{14}$ Postmodernism is not a break from modernity rather it is a rewriting of modernity. It is the representation of unpresentable. Lyotard is best known for his resistance against metanarratives western politics, aesthetics, and philosophy. $\mathrm{He}$ argues that little narratives resist such totalization of cultural representation hence they should take the place of metanarratives for they encourage difference. The definitive characteristic of Lyotard's description of Postmodernist concern with narrative is an opposition of 'little narratives' to grand or metanarratives. Briefly, a 'grand narrative' claims to be a story that can reveal the meaning of all stories, be it weakness or progress of mankind. Its metanarrative status comes from the fact that it talks about many narratives of culture so as to reveal a singular truth inherent in them. Meta or grand narratives manage a return to center and origin of meaning hence they are against Postmodernist stance. Cultural representations are distinctive therefore they cannot to be placed under uniformity. Mininarratives are in a series one comes after the other so that none of the narrative becomes a master narrative in the field of language-elements. This is what Lyotard ${ }^{15}$ referred in Postmodern Condition (1984), mininarratives germinate 'paralogy' hence consensus is never attained.

One of the most notable advancement in Postmodernism during 1980s is an enhanced distinction in Science Fiction, especially its subgenre Cyberpunk with regard to the works of writers such as Gibson, Sterling, Shirley and Bear. The narratives of these writers in particular and Cyberpunk Literature in general have delineated postmodern technologies of media, information and bioengineering. "From the 1970s onwards, as a result perhaps of the shift of dominant spoken of by Brian McHale, the epistemological distinction between narrated world and narrative mode gradually closed, as 'literary' fiction took over from science fiction the 'ontological' interest in creating and exploring other and multiple worlds". ${ }^{16}$ It happened because literary fiction started to borrow themes from Science Fiction while Science Fiction itself began to adopt from literary fiction particularly from the Postmodern cultural theory. Science Fiction initiated to portray the reality of contemporary society that has become digitalized. It communicates reality of a technological society because society itself has altered to be science fictionalized (Connor 1997).

Emergence of Cyberpunk as a representative genre is basically due to the shift in Postmodernism that is a shift from organic to cybernetic forms of discourse. Hayles ${ }^{17}$ offers an interpretive account of the rise of Cybernetics, and accompanying social and political implications. Science Fiction like Postmodernism brings in close encounters and confrontation of diverse worlds, a reader reconstructs the confrontation between real, predictable and practical world. Science Fiction and Postmodernist fiction travels on parallel yet independent tracks. Postmodern narratives preferably adapt the temporal dislocation instead of spatial from Science Fiction. They project worlds of the future other than distant worlds in other galaxies. Just as Postmodernist fiction has scrounged

\footnotetext{
${ }^{14}$ Jean Francois Lyotard, The Postmodern Condition: A Report on Knowledge. (Minneapolis: University of Minnesota Press, 1984)

${ }^{15}$ Ibid.

${ }_{16}$ Steven Connor, Op.cit. 134

${ }^{17}$ N. Katherine Hayles, How We Became Posthuman: Virtual Bodies in Cybernetics, Literature and Informatics. (The University of Chicago Press: Chicago, 1999)
} 
the ontological patterns from Science Fiction similarly Science Fiction also borrows from Postmodernism (McHale 1987) ${ }^{18}$. Science Fiction and Postmodern also shares the demonstration of intertextual field, "--- in which models, materials, images, 'ideas,' etc. circulate openly from text to text, and are conspicuously cited, analyzed, combined, revised, and reconfigured". It is Cyberpunk genre that has made Science Fiction a contemporary narrative and according to McHale "--- if cyberpunk did not exist, postmodernist critics like myself would have had to invent it. Perhaps we did, in a sense. Certainly, cyberpunk science fiction seems to be on the postmodernist critical agenda" (McHale 1992) ${ }^{19}$. Cyberpunk writers borrow motifs, models and styles from Postmodernist mainstream writers specifically Burroughs and Pynchon who have themselves utilized motifs, models and imagery from earlier Science Fiction narratives. Similarly, Postmodernism utilizes Cyberpunk themes and structures. McHale has termed Cyberpunk a repertoire of Science Fiction and Postmodernism due to its interdisciplinary nature.

Cyberpunk narratives share three prominent motifs with Postmodernism these are motifs of worldliness, centrifugal self and death. The ultimate parallel line between Postmodernism and Science Fiction is an ontological orientation of death. Postmodernism has always represented culture's struggle to master death, though symbolically similarly Cyberpunk narratives decenter death and mortality in various styles. Post-cyberpunk/Cyberpunk genre has altered the 'Old Wave' Science Fiction Star Track kind of space ontology and termed it inferior to the ontological orientation of death. "--- death, not space, is the main frontier of the imagination, beyond which only the most innovative adventurers boldly go (HcMale 1992) ${ }^{20}$.

Cyberpunk Literature is a genre of Science Fiction that emerged in 1980s after the publication of Gibson's Neoromancer in 1984 due to the above mentioned socio-cultural and technological transformations. The transition from first period of hard Science Fiction to second phase of Cyberpunk subgenre eventually culminated into the third phase of Post-cyberpunk subgenre in 1998. According to Person ${ }^{21}$, it is not only a change in name but also a complete transformation of themes and historical background. Person in 1998, coined the term 'Post-cyberpunk' in order to distinguish the Cyberpunk culture and fiction of $80 \mathrm{~s}$ from that of $90 \mathrm{~s}$ and beyond. He introduced the term 'Postcyberpunk' in an article, Notes Toward a Post-cyberpunk Manifesto (1999) published in a Science Fiction magazine. If early Cyberpunk novels were based on technology in Post-cyberpunk novels, the society is in fact technology.

Sterling ${ }^{22}$ has defined Cyberpunk genre, as 'radical Hard Science Fiction' for the novels are more technology oriented than the people. Post-cyberpunk has marked a shift towards social Science Fiction. Jameson ${ }^{23}$ says that Cyberpunk is "fully as much an

\footnotetext{
${ }^{18}$ Brian McHale, Op.cit., 13

${ }^{19}$ Brian McHale, Constructing Postmodernism. (London: Routledge, 1992) 14-15

${ }^{20}$ Ibid., 267

${ }^{21}$ Lawrence Person. Notes Toward a Post Cyberpunk Manifesto. Slashdot.org, (1999)

${ }^{22}$ Bruce Sterling, Mirrorshades: The Cyberpunk Anthology. (New York: Arbor House, 1986)

${ }^{23}$ Fredrick Jameson, Postmodernism, or, the Cultural Logic of Late Capitalism, (Durham: Duke University Press, 1991) 38
} 
expression of transnational corporate realities as it is of global paranoia itself". Snow Crash (1991) by Stephenson was the first novel to be branded as Post-cyberpunk. Person's distinction between Cyberpunk and Post-cyberpunk is based on the delineation of characters, technology, themes and plot structures. Murphy and Vint ${ }^{24}$ have also depicted a cultural transition in Cyberpunk to Post-cyberpunk. Cyberpunk Literature is about introduction of technology in culture and Post-cyberpunk is pervasiveness of this technology into human lives. According to Kelly and Kessel ${ }^{25}$ technology has not only changed our homes, schools, workplaces and governments but also our very senses, memories and consciousness. The transformations brought by information technology or informatics are of far reaching consequences than the ones produced by automobiles.

The 'Post' in Post-cyberpunk deals with transformation in themes that have occurred in Post-cyberpunk genre. Another obsession of Cyberpunk was to tell the stories of people like hackers, crackers and drug user whom the western writers traditionally ignored. Delineation of this street culture in Post-cyberpunk created a global depiction of society and previously marginalized characters took center in Post-cyberpunk novels (Kelly \& Kessel 2007). In Post-cyberpunk narratives "Asians, Africans and Latinos are no longer just sprinkled into stories as supporting characters, as if they are some kind of exotic seasoning. PCP writers attempt to bring them and their unique concerns to the center of their stories". ${ }^{26}$ The punk in Post-cyberpunk is a middle class representative, in this sense he is a true punk.

\section{Conceptual Framework}

This research is a discursive analysis it aspires to reveal and analyze many discursive practices present in selected novels in order to indicate that current technologies have almost changed the ontology of a human being along with culture and society. This study further endeavor to explore that how different phenomena such as gender, class, race, body, death and life are deconstructed to represent manifold identities associated with these so called static portents. A conceptual framework is formulated by the researchers with Postmodernist deconstruction of Metanarratives by Lyotard ${ }^{27}$ and Socio-Cognitive Approach of van $\mathrm{Dijk}^{28}$ in order to analyze the selected Post-cyberpunk novels.

\section{Methodology}

The first perspective of analysis is to critically explore various discursive practices. Then the focus is to highlight that how these discursive practices dismantle Metanarratives of identity with discursive tool of Socio-Cognitive Method. An analysis of different passages, incidents, characters and sentences is carried out in order to

\footnotetext{
${ }^{24}$ Graham J Murphy, and Sherryl Vint, Beyond Cyberpunk: New Critical perspectives. (London: Routledge, 2010)

${ }^{25}$ James Patrick Kelly, and John Kessel, Rewired: The Post-Cyberpunk Anthology. (San Francisco: Tachyon Publications. 2007)

${ }^{26}$ Ibid., 15

${ }^{27}$ Jean Francois Lyotard, Op.cit.

${ }^{28}$ Tuan van Dijk, Discourse and Context: A Sociocognitive Approach. (New York: Cambridge University Press, 2008)
} 
critically discuss that how grand narratives are subverted to denote novel ontologies of identity through techno-social aspects. A review of related literature has produced following research questions: How identity as a metanarrative is deconstructed in the selected novels through different discursive practices? How do discursive practices project Postmodernist tendencies in the selected Post-cyberpunk novels?

\section{Critical Discussion}

The plots of the Post-cyberpunk novels are simultaneously social and technological. Therefore, it is not only in social context that metanarratives of identity are dismantled but the discourse also subverts technology as a grand narrative. Accelerando (2005) decenters technology with the use of words like 'disposable', which subverts technological gadgets that are frequently in use. The discourse denotes that with passage of time economic value as well as usage of most modern technology would become obsolete. In the beginning of novel a notion of disposable technology has been introduced by Stross. "It's a disposable supermarket phone, paid for in cash-cheap, untraceable, and efficient" (Stross 2005) ${ }^{29}$. Subversion of nuclear power, economic and political metanarrative is enlisted in these lines, "Manfred re-enters Europe through an airport that's all twentieth-century chrome and ductwork, barbaric in its decaying nuclear-age splendor". Novel represents an establishment of another technology far superior than nuclear power namely, the information technology. Another significant discursive element of novel is subversion of books as old and obsolete form of technology in the scene where Manfred went to meet Gianni and he saw piles of books in his study. "Opposite to the bench is a wall occupied from floor to ceiling by bookcases: Manfred looks at the ancient, low density medium and sneezes, momentarily bemused by the sight of data density measured in kilograms per megabyte rather than vice versa".

In the last part of novel that is more philosophical than technological through the old version of Pamela metanarrative of technological development is put to prove. Discussion between Sirhan and Pamela delineated that excess of technological advancement may lead to destruction of sublime phenomena like humanity and relationships. Pamela has specifically referred to the period of presingularity when "humans were real humans, work was real work, and corporations were just things that did as we told them". Subversion of economy is one of the basic traits of novel which runs side by side with technological plot. The economics of scarcity is subverted in following lines that represents Annette's school of thought. "She still believes in classical economics, the allocation of resources under conditions of scarcity. Information doesn't work that way". Accelerando frequently represents deconstruction of capitalism and multinational consumers cultural, "Manfred has a suite at the Hotel Jan Luyken paid for by a grateful multinational consumer protection group, and an unlimited public transport pass paid for by a Scottish sambapunk band in return for services rendered".

\footnotetext{
${ }^{29}$ Charles Stross, Accelerando. (New York: ACE Books, 2005) 5-72
} 
The context of Accelerando (2005) is as vast as a universe from hand-made Afghani rugs to MiGs and Kalashnikovs. Subversion of Christianity is also discursively represented in the discourse. "People are putting their trust in the Christian Coalition and the Eurocommunist Alliance-always a sign that the times are bad---". ${ }^{30}$ The discourse decenters Christianity by labeling it as obsolete and out of practice when Jack in a guise of Manfred reached the wrong church in search of Franklin Collective. "Christianity has been deeply unfashionable in Scotland for some decades, and the church that currently occupies the building has certainly moved with the times in an effort to stay relevant". Discussions related to Franklin Collective also lead towards subversion of Catholic sect of Christianity that staunchly believes in religious dogmas. These religious doctrines are decentered by an ironical comparison with borganism a kind of sect of information technology. Just as in Christianity the leaders are known as saints or priests similarly in borganism they are known bodhisattva, hence Franklin Collective and his borganism is a metaphor for subversion of Christian theology.

Parallel to the subversion of Christianity runs deconstruction of Islam in the backdrop of information technology that stands to dismantle metanarrative of religion. "The Malaysian government has announced the goal of placing an imam on Mars within ten years, but nobody else cares enough to try". Question of modernization and Islam is also one of the discursive practices of novel that is repeatedly addressed through Sadeq. He is a representative of Shi' ite sect of Islam that is considered to be more moderate and accommodating with the novelties of time. Terms like 'isnads' and 'mujtahid' are used to represent Islamic modernization that subverts stereotype version of orthodox Islam. The stereotype concept of a Muslim cleric as a terrorist or mutant to fight and indulge in destructive activities is further dismantled through Sadeq. He is represented more as a scholar and less warrior. "--- he knows that he is less a warrior than a scholar".

The discourse further deconstructs grand narrative of death that subverts the dichotomy between life and death. "Today's increasingly automated corporations don't understand mortality---". The narrative of death is further decentered in the following lines. "Experiments in digitizing and running neural wetware under emulation are well established; some radical libertarians claim that, as the technology matures, death-with its draconian curtailment of property and voting rights - will become the biggest civil rights issue of all". ${ }^{31}$ Subversion of death is also exemplified where the discourse refers to a world of minds created by brain uploads, "Death is abolished, life is triumphant". Along with death grand narrative of immortality is also decentered in the last part of novel when Pamela tells Sirhan that life prolongation is not appropriate rather it disturbs the order of life cycle. The discourse also subverts notion of permanency and stability, it discursively propagate an idea of transformation and modification. It denotes that to change accordingly with the pace of time and technology is a need of time for fluidity of information technology will stand nothing stagnant and constant.

The Windup Girl (2009) embodies discursive aspects of a society that has expanded in bio-technology then it contracted to suffer the consequences of bioterrorism due to

${ }^{30}$ Ibid., 53- 136

${ }^{31}$ Charles Stross, Accelerando. (New York: ACE Books, 2005) 88-214 
which contagious diseases and plagues are rampant that has made human life challenging. Apart from these novel also subverts many socio-political traits such as race, religion, class and colonization. Subversion of race is initiated when Bangkok, the City of Divine Beings is portrait along with its Buddhist monks. "Saffron-robbed monks stroll along the sidewalks under the shade of black umbrellas". The novel deconstructs religion exclusively through racial genocide based on religious differences. Subversion of religion is evident from the beginning of the novel when Emiko was thinking about herself and her artificially constructed being through genetic engineering:

Nor human, certainly, but not the threat the people of this savage basic culture make her out to be. Certainly not the devils that the Grahamites warn against at their pulpits, or the soulless creatures imagined out of hell that the forest monk Buddhists claim; not a creature unable to ever achieve a soul or a place in the cycles of rebirth and striving for Nirvana. Not the affront to the Q'ran that the Green Headbands believe. ${ }^{32}$

This single passage at a time deconstructs Islam, Christianity and Buddhism. It propagates that though Emiko was created from a test tube yet she is not a soulless toy to be played with. Her creation is a challenge for religious extremists who can only assume that organically produced things are real, natural and authentic rest is sinful and lifeless rather soulless and worthless. Subversion of Christianity is suggested when Emiko and Anderson were indulged in a discussion. 'Grahamites.' She makes a face. 'So concerned with niche and nature. So focused on their Noah's ark, after the flood has already happened" (The term Grahamites refers to the followers of Sylvester Graham whereas in the novel it generally denotes the orthodox Christians). ${ }^{33}$ These lines clearly depict deconstruction of Christian beliefs that according to Emiko are not practical and flexible. Rather the lines suggest a rigid mindset that does not welcome change but tries to resist it. Anything that does not fit into their formula of nature and niche is not real and authentic for them.

The text also displays ample turns in plot that subvert religion based racial genocide. An example of this kind of racial genocide is represented though the murder of Hock Seng's clan in Malaya through Muslim Green Headbands who wanted to convert them to Islam by force. Hock Seng's entire property was burnt and his wives along with his daughters and sons were slaughtered. Once he was the head of Three Prosperities shipping company whereas after the Incident he became a yellow card refugee and lost his entire family. He was left with only a single daughter who was also murdered when they were trying to escape to Bangkok. "He and Forth Daughter, that useless waif, the only one he could preserve, hid among the piers and rocking boats, and when darkness fell completely, he guided her down to the water---".

A reference to Malayan Incident of 1963 is quite a discursive example that signifies racial riots and killings. As the dispute was between the Chinese and Malayan Muslims it took a racial form and caused death of many. Massive bloodshed of Malaya Chinese represents racial riots and genocide. Green Headbands became so much aggressive that they did not spare a single person who helped escape Chinese refugees trying to leave

${ }^{32}$ Paolo Bacigalupi, The Windup Girl. (New York: Night Shade Books, 2009) 40

${ }^{33}$ Ibid., $78-128$ 
the country. "The Green Headbands has already sail the coasts searching for refugees. Their net is wide and deep. And they slaughter those they catch". Deconstruction of religion and race is also evident from the following passage where Jiadee made a comparison between Chaozhou Chinese and Malayan Chinese: "If the Malayan Chinese had been half as clever as the Chaozhou, they would have converted to Islam generations ago, and woven themselves fully into the tapestry of that society". ${ }^{34}$

One of the main traits of Post-cyberpunk is to discourage established class structure. Hence, following the traditions of Post-cyberpunk The Windup Girl projects disillusionment with class based society for which it subverts slavery, and prescribed roles of lower and middle classes in a hierarchy based society. It challenges conformity and obedience through characters like yellow card Malay Chinese Hock Seng and a windup Emiko who is solely built to serve yet she rebels. Subversion of class is exemplified through depiction of subaltern class, low paid workers and yellow card refugees. Hock Seng's character is very crucial for subversion of class as his persona embodies a contrast between rich and poor. Imperialism is not a novel aspect of human society rather it is a centuries old tradition of orientalist to invade the orient for sake of plundering their land and resources. A passage related to Akkarat and Anderson characterizes imperialism since the time when first group of missionaries invaded Asian peninsula for the reason to convert them to Christianity. Below mentioned lines simultaneously decenter colonization and the colonizers' intruding policies. Likes wise they denote subversion of globalized economy that is a slogan of imperialists to take hold of the resources of earth and to bring other nations into their servitude:

Ever since your missionaries landed on our shores, you have always sought to destroy us. During the old Expansion your kind tried to take every part of us. Chopping off the arms and legs of our country. It was only through our kings' wisdom and leadership that we avoided your worst. And yet still you weren't done with us. With the Contraction, your worshipped global economy left us starving and over-specialized. ${ }^{35}$

\section{Findings}

The discursive analysis has suggested a conversational aspect of novels that how they are associated and correlated to the society by depiction of various features of society and culture. The novels have projected various discursive elements through which metanarratives of identity are decentered. Accelerando deconstructs the nuclear power and technology by presenting them as obsolete and out of practice likewise the novel also decenters death through Manfred, Annette, Pamela, Sirhan, Amber, Sadeq and many other characters. Destabilization of global politics, economy and capitalism is also one of the landmarks of novel other than the deconstruction of religion as a metanarrative by subversion of two main religions Islam and Christianity.

The Windup Girl has delineated and deconstructed many discursive elements such as, colonization, bioterrorism and genetic engineering sidewise it has also subverted

${ }^{34}$ Ibid., 130

${ }^{35}$ Ibid., 166-167 
technology, class, religion and power. The novel speaks against religious and racial genocide and socio-political imperialism. It deconstructs grand narratives like Islam, Christianity and Buddhism. It subverts the money based economy and also decenters petroleum. In short all the novels decenter the notion of stability and permanency and project that transformation and alteration should be adopted in order to think out of box and against predefined parameters for identifying things, people and institutions. Similarly, these novels dismantle the power structure through various characters, incidents and passages.

\section{Conclusion}

The historical perspective of Science Fiction Literature from Pre to Post Cyberpunk is discussed in order to authenticate that Post-cyberpunk Literature is a practical subgenre of Science Fiction Literature. And also to illustrate that Post-cyberpunk subgenre is an emerging genre of Postmodernist Literature, and how coherent it is in the delineation of connection between current society and technology? How contemporary society and culture became technology oriented and how information technology became pervasive to the core? It aspires to explore a genre and target the area of research not only to represent but also to validate that although Post-cyberpunk is contemporary, social and technological yet it is Postmodernist to the core.

\section{Bibliography}

Bacigalupi, Paolo. The Windup Girl. (New York: Night Shade Books, 2009).

Baudrillard, Jean. Simulacra and Simulation. (S. F. Glaser, Trans.). (Ann Arbor: University of Michigan Press, 1994).

Bennett, Andy. Culture and everyday Life. (London: Sage Publications, 2005).

Bukatman, Scott. Terminal Identity: The Virtual Subject in Postmodern Science Fiction. (Durham: Duke UP, 1993).

Cavallaro, Dani. Cyberpunk and Cyberculture: Science Fiction and the Work of William Gibson. (London: The Athlone Press, 2000).

Connor, Steven. Postmodernist Culture: An Introduction to Theories of the Contemporary ( $2^{\text {nd }}$ ed.). Malden, (Massachusetts: Blackwell Publishing, 1997).

Hassan, Ihab. "Pluralism in Postmodern Perspective". Critical Inquiry, no.12. 3 (1986).

Hayles, N. Katherine. How we Became Posthuman: Virtual bodies in Cybernetics, Literature and Informatics. (The University of Chicago Press: Chicago, 1999).

Jameson, Fredrick. Postmodernism, or, the Cultural Logic of Late Capitalism. Durham: Duke University Press, 1991 
Kelly, James Patrick, and John Kessel. Rewired: The Post-cyberpunk Anthology. (San Francisco: Tachyon Publications, 2007).

Lyotard, Jean Francois. The Postmodern condition: A Report on Knowledge. (Minneapolis: University of Minnesota Press, 1984).

McHale, Brian. Postmodernist Fiction. (GB: Methuen, Inc, 1987).

McHale, Brian. Constructing Postmodernism. (London: Routledge, 1992).

Murphy, Graham J., and Sherryl Vint. Beyond Cyberpunk: New Critical Perspectives. (London: Routledge, 2010).

Person, Lawrence. "Notes toward a Postcyberpunk Manifesto". Slashdot.org, (1999).

Richardson, Michael. The Experience of Culture. (London: Sage Publication, 2001).

Strinati, Dominic. An Introduction to Theories of Popular Culture. (New York: Routledge, 1995).

Stross, Charles. Accelerando. (New York: ACE Books, 2005).

Turkle, Sherry. Life on the screen: Identity in the age of the internet. (London: Simon \& Schuster, 2011).

Tuan van Dijk. Discourse and Context: A Sociocognitive Approach. (New York: Cambridge University Press, 2008). 